\title{
Cows‘ milk productivity determining method
}

\author{
Valentin Golovan ${ }^{1, *}$, Mariya Galicheva ${ }^{3}$, Denis Osepchuk ${ }^{1}$, Tamara Nepshekueva $^{1,2}$ and \\ Aleksandr Suvorov ${ }^{1}$ \\ ${ }^{1}$ Krasnodar Research Centre for Animal Husbandry and Veterinary Medicine, 4, Pervomaiskaya Str., \\ 350055, Znamensky village, Krasnodar, Russia \\ ${ }^{2}$ Kuban State Agrarian University named after I.T. Trubilin, 13, Kalinina Str., 350000, Krasnodar, \\ Russia \\ ${ }^{3}$ Maikop State Technological University, 191, Pervomayskaya Str., 385000, Maykop, Republic of \\ Adygeya, Russia
}

\begin{abstract}
Cows' milk productivity determining method of includes: determining the amount of milk during control milking, milk sampling and analyzing its fat and protein content for each milking, they are the same indicators for the day; calculating the conversion coefficients of milk amount and the mass fraction of fat and protein for each milking into daily indicators. Then one control milking is performed per day, and the same indicator is calculated for the same type of feeding, maintenance, and milking based on its indicators multiplied by the corresponding coefficient. The time intervals between milking being unequal, milk productivity is more accurately determined by a single milk yield after a longer interval between them. For this method, milk cows are taken from the tenth day of lactation and more. The method allows reducing labor costs and working hours of operators and laboratory assistants to daily determine the dairy productivity of cows, as well as to reduce the stress load on animals.
\end{abstract}

\section{Introduction}

In the technology of milk production in financial planning, it is mandatory to determine the milk productivity of cows. The basis of this is the determination of the cows' dairy productivity per day during control milking. They are held as many times a day as these animals are usually milked. Each milking the amount of milk is determined, the milk is mixed and a sample is taken from it for composition analysis; from these samples, an average sample of milk per day is made in proportion to the amount of milk in each milking [1]. The chemical composition of milk is determined in it. The cow secretes milk after calving for an average of 10 months.

In breeding farms, control milking is performed during the day, taking into account the time intervals between milking at different stages of lactation [2] in 10 days, 3 times a month, and on commodity farms and complexes - once a month. The amount of milk for 10 days is determined by multiplying its amount per day by 10 , and per month - by $30 \pm 1$ (by the number of days). And based on these data, the milk productivity per lactation is determined. This is necessary to determine the breeding qualities of animals, to use

\footnotetext{
* Corresponding author: skniig@yandex.ru
} 
valuable heredity in improving the breed, turning the outstanding qualities of individual animals into group ones [3] when laying lines, in identifying the prepotency of producing bulls in transferring properties to their daughters by inheritance, when studying the constitutional types of cattle.

When carrying out control milking (on farms), the quantity and quality of milk per day is determined, as a rule, the amount of milk, the concentration of fat and protein in it in different breeds of cattle are determined. For example, in three times a day milking, the average milk sample is made according to its quantity in the morning, at midday and in the evening, both with manual and machine milking [4].

However, the production of milk requires constant improvement of technical progress. This requires, for example, conducting experiments using the Latin square method, determining milk yield and milk composition under the influence of certain factors for a separate short time period or even for a day [8].

Thus, it is experimentally established that when cows of different breeds are milked three times a day, the secretion of milk and fat (up to 25\%) is higher than when machine milking is performed twice a day [8] in different climatic zones of our planet. This increase feed activity and improves the condition of the udder $[8,10]$. For this reason, we have taken three-time milking as the basis.

Milk productivity increases when animals are acclimated to local conditions [8], comfortable conditions for animals in the form of area holding are created: the time of lying down and chewing increases [9]. On the contrary, high air temperature causes heat stress, impairs health, reduces milk yield, and the quality of milk and dairy products [11].

An optimal range of microorganisms species in the rumen, selection of conditions for their development and interaction are required, which is useful for the host organism and productivity [15].

The composition and quality of feed, for example, hay, depends on the vegetative stage of plants when mowing [16]; the amount of grain such as barley and corn in the diet affects the fermentation processes in the rumen, the frequency of food giving [13] affects the concentration of non-esterified fatty acids and of beta-hydroxybuterate in the blood serum have an effect on milk productivity [14].

Our proposed method for determining milk productivity will increase the researchers' productivity, the accuracy of results, and the livestock productivity.

Milk that is constantly formed in the udder between milking fills the udder's storage system. The capacity of the udder includes the volume of its cistern, alveoli, and ducts (which make up the alveolar part of the gland).

The degree of tension (tone) of the udder ducts and cistern is of great importance, which varies depending on the filling of the udder with milk, increasing in proportion to the time interval between milking to physiological values (measured in millimeters of mercury or water column).

By the beginning of the next milking, the udder tanks (the cistern part of the milk) in cows contain from 4 to $20 \%$ of milk, the main part of the secret $-80-96 \%$ is in the alveoli and small ducts of the mammary gland (the alveolar part), the milk in these parts of it being of different fat content. The alveolar part of the milk yield is fatter than the cistern part.

In response to the stimulation of the mammary gland receptors and the arrival of signals to the brain, its hypothalamus department releases the hormone oxytocin through the posterior pituitary into the blood, which reaches the mammary gland with blood and causes the contraction of myoepithelial (muscle) cells around the alveoli, while increasing pressure on the alveoli and secretory cell walls. As a result, the components of the milk are actively transferred from the secretory cells to the alveolus cavity, and from there they are squeezed into the ducts, including fat balls. In this case, part of the fat balls leaves the secretory cells 
into the alveoli and then directly into the lumen of the milk channel during milking. Therefore, thanks to the reflex, the fat content of milk increases abruptly as it is milked.

The composition of the milk depends on the interval between milking and feeding and maintenance during the day. Therefore, the milk composition is different during different milkings of the same day.

The increase in fat content during milking occurs abruptly at the time of the onset of the milk flow reflex. As a rule, the unconditional reflex of milk flow occurs 25-40 seconds after the beginning of udder irritation and continues normally from 4 to 8 minutes, gradually weakening. There is also a difference in the strength of the milk flow reflex. It depends in particular on the degree of udder filling with milk, which in turn depends on the time between milking.

The degree of udder filling with milk is higher at the 12-hour interval between milking than at the 6-hour interval. If it is less than 4 hours - then the reflex is weak. Therefore, this interval is not used for machine milking. The interval between milking should not exceed 14-16 hours, since the milk pressure in the container increases and its secretion is inhibited. Therefore, cows are machine milked optimally with an interval of 6-12 hours.

The strength of compression of the alveoli and the completeness of emptying the udder during milking depend on the strength of the reflex. The strength of the reflex depends on the amount of oxytocin accumulated in the supraoptic and paraventricular nuclei of the hypothalamus. At an interval of 6 hours, the capacitive system is not fully filled. The amount of alveolar milk in the total milk yield increases, and the milk fat content obtained during milking is higher than with a longer between-milking period. At the same time, the fullness of the milking directly depends on the strength of the reflex.

\section{Materials and methods}

Without the milk flow reflex, a cow will not be fully milked. Machine milking is carried out with the mandatory triggering of the milk flow reflex manually for 30-40 seconds, or automatically by a robot.

Before or during milking, sudden negative stimuli (such as falling objects) causing animal fright, stress, and a reflective release of the adrenaline hormone (from the adrenal cortex) that inhibits the milk flow reflex should be excluded. After this, a second triggering of the milk flow reflex is possible, but milking fullness may decrease. Therefore, stressful situations during milking are excluded. The machine milking rules prescribe stereotypical milking without stress, which is recommended by us as well.

Milk flow reflex triggering is combined with the sanitary treatment of the udder (washing, wiping the udder and nipples), and milking of the first streams, during which the udder receptors are irritated.

It was found that milk composition during each milking within the adjacent days negligibly fluctuates with the stereotypical keeping, milking and year-round feeding. Therefore, stereotypes are strictly observed in practice.

On modern farms, control milking is usually carried out with a milking machine in a portable bucket or in a milk pipeline through individual milk meters.

A method is known for taking medium samples from milking buckets, in which milk is poured into a milk meter, where it is mixed with a float, then a portion of milk is taken with a sampler to make an average sample. The tube-sampler with a diameter of $9 \mathrm{~mm}$ is immersed into the milk mass in a cylindrical milk meter strictly perpendicular and slowly so that the level of milk in the sampler and the container during the immersion is the same. The sampler as though cuts out a column of milk. After that, the upper opening of the tube is closed with the thumb, and the milk is carefully transferred to a glass bottle for testing, from 20 to $250 \mathrm{ml}$. The milk of all milking during the day (morning, midday, evening) is 
placed in the same bottle in the same way. A device for selecting milk from the container (1) should be used. This creates an average sample, by which the composition of milk on average per day is determined. When creating an average sample per day from milk yields of different composition, the amount of milk must be taken into account. This is provided by a cylindrical milk meter and a sampler. The disadvantage is that the average sample is obtained in different volumes, and the samples sent to the laboratory are of the same volume. Therefore, you have to pour it into standard cups. In addition, with such a system, labor costs for compiling an average sample and control milking by the number of milking per day are large.

A method is known for sampling milk yields with different volume scoops.

This time-consuming method requires control milking during the day according to the number of milkings in the presence of the experimenter, which is a stress factor for the animal, as well as the milking time lengthening. When the control milking is reduced, the stress load on the animals is reduced, respectively. During the control milking, the milking time of a group of cows is increased by $25 \%$ compared to the usual milking. When milking three times a day, the milking time increases by $(25 \% \times 3)=75 \%$. At the same time, the work with scoops is time-consuming and inaccurate.

The main drawback of the known methods for determining the average milk sample per day is their incompatibility with modern robotic milking machines equipped with individual milk counters that allow you to select the average milk sample in a beaker by composition only for one milking from each cow [2].

The technical result of the proposed method is the labor costs and working time of operators and laboratory assistants reduction to determine the dairy productivity of cows per day, as well as the reduction of the stress load on animals.

The technical result is achieved by the fact that, according to the proposed method for determining cows' milk productivity per day, including test milking, sanitary udder preparation, compliance with the rules of cows' machine milking, determination of the milk amount, milk sampling and analysis in its components content is conducted separately for each milking, next, the coefficients of converting the amount of milk and the mass fraction of each ingredient for each milking into daily values according to the formulas developed by us are calculated.

Calculation of indicators conversion coefficients for milking into indicators for a day is carried out no more than once a year during lactation. Herewith, the coefficients for the mass fraction of fat, protein, and others are calculated according to the yield. After that, in the future, one control milking is carried out per day, and its indicators, multiplied by the corresponding calculation coefficient, for each milk ingredient, the same indicator is calculated for a day, months and year with the same feeding, content and milking type.

Verification of the claimed method was performed in the OPH "Ladozhskoe" of the Ust-Labinsk district of the Krasnodar Territory on the MTF, where under the tethered walking system 200 Black-Mottled cows are kept in standard barns, with the same type of feeding during the year, with an annual milk yield of $7000 \mathrm{~kg}$ per cow, with the ADM-8 milking installation with DeLaval devices with individual milk counters at three times a day milking, intervals between milking being 12-6-6 hours stereotypically observed all year round. The factory individual milk counter of the IUM-1 type (or another) automatically determined the amount of milk during milking and selected average milk sample per milking for each cow in a measuring beaker.

The first experimental group included all 83 milker cows from 3 production groups of the 2nd cowshed, and the second group included 102 milker cows from 3 production groups of cowsheds 1 and 3. Cows were included into groups from the 10th day after calving to the period of starting different (1-5) lactations. 
The conditions of keeping, the same type of feeding, milking, and maintenance staff were similar during the year.

Milk samples were taken and prepared for analysis in accordance with GOST 520542003.

The composition and quality of milk was determined in the laboratory of the North Caucasus Research Institute of Animal Husbandry, Krasnodar in compliance with GOST R 52054-2003, the mass fraction of fat in accordance with GOST 5867-90, and protein in accordance with GOST 25179-2014.

In the second group, the similar work was carried out six months after the first one.

In both experimental groups, the work was carried out in two periods (table. 1).

In the first control period, the amount of milk and its composition were determined for cows per each of the three milkings per day (morning, midday and evening) separately, and the indicators for the day were calculated by summation.

In the second experimental period everything was carried out as in the first one and then the calculation of the amount and composition of milk per day for one milking was performed using coefficients.

Table 1. The experiment scheme in determining milk composition and amount per day on the ADM-8 installation.

\begin{tabular}{|l|l|}
\hline \multicolumn{1}{|c|}{ № of the period } & \multicolumn{1}{c|}{ Control milking } \\
\hline 1 Control period & $\begin{array}{l}\text { The amount of milk and its composition for each milking (per } \\
\text { day) is determined separately, then the calculation is performed } \\
\text { per day }\end{array}$ \\
\hline 2 Experimental period & $\begin{array}{l}\text { It is carried out in the same way as in the control, then the } \\
\text { calculation of the amount and composition of milk is performed } \\
\text { for 1 milking }\end{array}$ \\
\hline
\end{tabular}

Then the results were compared with the control.

\section{Results}

The determination of the quantity and composition of milk per day, adopted by us in the first period, is absolutely accurate (table. 2).

Table 2. Actual average milk productivity of cows for each milking with three times milking and per day, $\mathrm{n}=83$.

\begin{tabular}{|l|c|c|c|c|}
\hline \multirow{2}{*}{\multicolumn{1}{|c|}{ Indicators }} & \multicolumn{3}{c|}{ Milking } & \multirow{2}{*}{ Per day } \\
\cline { 2 - 5 } & morning & midday & evening & \\
\hline Yield, $\mathrm{M} \pm \mathrm{m}, \mathrm{kg}$ & $12.6 \pm 0.4$ & $5.8 \pm 0.2$ & $6.8 \pm 0.2$ & $25.2 \pm 0.8$ \\
\hline Mass fraction of fat, \% & $3.51 \pm 0.08$ & $4.85 \pm 0.11$ & $4.30 \pm 0.10$ & $4.03 \pm 0.09^{*}$ \\
\hline Mass fraction of protein, \% & $3.12 \pm 0.01$ & $3.10 \pm 0.01$ & $3.13 \pm 0.01$ & $3.12 \pm 0.01^{*}$ \\
\hline
\end{tabular}

Note: $\mathrm{n}$ - cows' number; $\mathrm{M}$ - the arithmetic mean; $\mathrm{m}$ - mistake $\mathrm{M}$.

The quantity and composition of the milk sample was determined for each milking and per day for each cow.

In the first experimental group, 83 cows were of different ages (from 1 to 4 lactation) and lactation stages (from 1 to 10 months.). They had indicators in the I control period (after 10 days of lactation before the end of lactation period): $\mathrm{M} \pm \mathrm{m}, \mathrm{Cv}$ (coefficient of variation) and limits of indicators, respectively: milk yield $25.2 \pm 0.8 \mathrm{~kg}, 27 \%$, lim 13-46, $8 \mathrm{~kg}$; mass fraction of fat (or $\%$ of fat) $4.03 \pm 0.09 \%, 19.45 \%$, lim 2.8-7.86; mass fraction of protein (\%of protein) $3.12 \pm 0.01 \%, 3.02 \%$, lim 2.94-3.32 (table. 2). 
The variation coefficients and indicators limits for milk yield and fat $\%$ are high, since all cows of production groups are taken into the experiment. They are much lower in protein.

Then the recalculation indexes coefficient per milking into indexes per day were found through the division of day indexes by the similar ones per milking: separately for morning, midday and evening according to the given formulae:

$$
\begin{gathered}
U_{I}+U_{2}+U_{3}+U_{n}=U_{C} \\
U_{C} / U_{I}=K_{U I} \\
U_{C}=U_{I} \times K_{U 1} \\
\left(U_{I} \times Z_{1}+U_{2} \times Z_{2}+U_{3} \times Z_{3}+U_{n} \times Z_{n}\right) /\left(U_{I}+U_{2}+U_{3}+U_{n}\right)=\left(U_{C} I\right) / U_{C}=Z_{C} \\
\mathrm{Z}_{\mathrm{C}} / \mathrm{Z}_{1}=\mathrm{K}_{\mathrm{Z} 1} \\
\mathrm{Z}_{\mathrm{C}}=\mathrm{Z}_{1} \times \mathrm{K}_{\mathrm{Z} 1} \\
\mathrm{~B}_{\mathrm{C}} / \mathrm{B}_{1}=\mathrm{K}_{\mathrm{B} 1} \\
\mathrm{~B}_{\mathrm{C}}=\mathrm{B}_{1} \times \mathrm{K}_{\mathrm{B} 1}
\end{gathered}
$$

Where $\mathrm{U}$ - yield; $\mathrm{U}_{1}$ - for the first milking; $\mathrm{U}_{2}$ - for the second milking; $\mathrm{U}_{3}$ - for the third milking; $\mathrm{U}_{\mathrm{n}}$ - for the following milkings; $\mathrm{U}_{\mathrm{C}}$ - yield for a day;

$\mathrm{U}_{\mathrm{C}} \mathrm{I}$ - daily milk yield, milk with $1 \%$ fat.

$\mathrm{Z}$ - mass fraction of fat, in $\%$;

$1,2,3, \ldots \mathrm{n}$ - serial number of milking during the day;

$\mathrm{C}$-index for the day;

$\mathrm{K}$ - index conversion factors for milking for the day into the daily index;

$\mathrm{B}_{\mathrm{C}}-\%$ protein average for the day;

$\mathrm{B}_{1}-\%$ protein per one milking.

For the first group (83 cows), these recalculation coefficient indexes for milking per day are shown in (table. 3).

For each of the 83 cows in experimental group 1, the calculation was made using the coefficients of indicators for one milking into per day ones.

Table 3. Coefficients $(\mathrm{K})$ of indicator recalculation for milking into daily one, at three times milking of cows per day on group No. $1(\mathrm{n}=83)$.

\begin{tabular}{|l|c|c|c|}
\hline \multirow{2}{*}{\multicolumn{1}{|c|}{ Indicators }} & \multicolumn{3}{c|}{ Milking } \\
\cline { 2 - 4 } & morning & midday & evening \\
\hline $\mathrm{K}_{\mathrm{Y}}($ yield $)$ & 1.984 & 4.379 & 3.735 \\
\hline $\mathrm{K}_{\mathrm{J}}(\%$ fat $)$ & 1.148 & 0.831 & 0.937 \\
\hline $\mathrm{K}_{\mathrm{B}}(\%$ protein $)$ & 1.000 & 1.006 & 0.997 \\
\hline
\end{tabular}

The daily milk yield and the average daily yield, mass fraction of fat and protein in milk are determined based on the indicator calculation coefficients: milk yield, the mass fraction of fat and protein for a separate milking per day, found according to the given formulae.

Example of the index calculation for milking into the per day one in cows of group №1.

In the morning, cow № 117 had $15.0 \mathrm{~kg}$ of milk yield, with $3.6 \%$ of fat and $3.0 \%$ of protein. Its productivity per day is calculated using the coefficients given for morning milking (in table 3 ) with an accuracy of 2 decimal places.

Productivity indicators for the day in this cow are equal:

- $\quad$ morning yield $15.00 \mathrm{~kg} \times 1.984($ coefficient $)=29.76 \mathrm{~kg}$; 
- mass fraction of fat $3.6 \% \times 1.148$ (coefficient) $=4.13 \%$;

- mass fraction of protein $3.0 \% \times 1.000$ (coefficient) $=3.00 \%$.

Thus, during the day, cow №117 secreted $29.76 \mathrm{~kg}$ of milk with the fat content of $4.13 \%$ and the protein content of $3.00 \%$.

Similarly, the daily productivity of cow No. 720 is calculated according to the midday milking. At midday, it gave $6.0 \mathrm{~kg}$ of milk with the fat content of $4.5 \%$ and the protein content of $3.2 \%$.

Based on this data for the midday milking the productivity of this cow per day is calculated:

- the midday yield of $6.0 \mathrm{~kg} \times 4.379$ (coefficient) and we get a daily yield of $26.27 \mathrm{~kg}$;

- mass fraction of fat $4.5 \% \times 0.831$ (coefficient) $=3.74 \%$;

- mass fraction of protein $3.2 \% \times 1.006$ (coefficient) $=3.22 \%$.

Consequently, during the day, cow No. 720 gave $26.27 \mathrm{~kg}$ of milk with the fat content of $3.74 \%$ and the protein content of $3.22 \%$.

Similarly we calculate the daily productivity based on the data for the evening milking.

For example, in the evening, cow № 830 gave $7 \mathrm{~kg}$ of milk with a fat content of $4.2 \%$ and a protein content of $3.3 \%$.

The daily productivity indicators for evening milking are calculated:

- $\quad$ Evening yield $7 \mathrm{~kg} \times 3.735$ (coefficient) $=26.15 \mathrm{~kg}$ for day;

- mass fraction of fat $4.2 \% \times 0.937$ (coefficient) $=3.94 \%$ for day;

- mass fraction of protein $3.3 \% \times 0.997$ (coefficient) $=3.29 \%$ for day.

Thus, dairy productivity of a cow per day can be calculated for one milking out of three.

This method is valid, since the coefficients are calculated for this particular herd with the adopted production technology with an interval between milking: 12: 6: 6 hours.

The found difference between the average indicators of actual daily ones and the calculated ones for the production groups of 22, 28, and 33 cows (83 in total) was found to be unreliable in terms of milk yield, fat $\%$, and protein $\%$, as well as for 83 animals in general.

For 83 cows in the group, the difference was in the morning, midday and evening indicators, respectively: in the yield, $\mathrm{kg} 0,019 \quad(\mathrm{td}=0.018) ; 0.13 \quad(\mathrm{td}=0.117)$ and $0.087(\mathrm{td}=0.081)$; in fat. in \%: $0.003(\mathrm{td}=0.027) ; 0.000(\mathrm{td}=0.00) ; 0.004(\mathrm{td}=0.029)$; in protein. in \%: $0.000(\mathrm{td}=0.00) ; 0.0003(\mathrm{td}=0.019) ; 0.010(\mathrm{td}=0.010)$. In this case, the $\mathrm{td}$ values indicate the lack of confidence $(\mathrm{P}>0.05)$ in the differences between the actual and calculated indicator (table. 4).

A high pair correlation of the same daily values calculated for one milking and actual daily values for all production groups of operators was established, as well as for the first group as a whole (td<2.0; table. 4$)$.

In general, the pair correlation coefficients for the first group are calculated between indicators for milking and per day, taken for each of the 83 cows in terms of indicators for the first and second periods of experiment (table. 4).

In the morning, at midday and in the evening, they are very high and reliable. For milking in the morning, at midday and in the evening, respectively, according to the milk yield: $\mathrm{r}=0.991,(\operatorname{tr}=37.9) ; \mathrm{r}=0.894,(\operatorname{tr}=31.1) ; \mathrm{r}=0.991, \quad(\operatorname{tr}=36.8) ;$ by fat $\%: \mathrm{r}=0.987$, $(\operatorname{tr}=30.9) ; \mathrm{r}=0.862,(\operatorname{tr}=8.67) ; \mathrm{r}=0.987,(\operatorname{tr}=30.9)$; by protein $\%: \mathrm{r}=985,(\operatorname{tr}=29.4) ; \mathrm{r}=0.751$, $(\operatorname{tr}=5.79) ; r=0.985$, (tr=29.4).

Further, the degree of difference in milking of the calculated daily indicator (without a sign) with the actual one, as a percentage for each cow, group of operators, and in general for group №1 is established.

For group №1, in 83 cows on average the yield, \% fat and \% protein differ from the actual indicators, respectively, in percentages: in the morning: $3.85 \pm 0.35 ; 3.75 \pm 0.29$; 
$0.51 \pm 0.05$; at midday $12.97 \pm 1.18 ; 9.14 \pm 0.73 ; 1.70 \pm 0.14$; in the evening: $3.81 \pm 0.35$; $3.81 \pm 0.35 ; 0.60 \pm 0.05$.

Hence: 1 . The most stable indicators for all milkings by protein percentage.

2. In the morning and in the evening, the error for cows in all indicators does not exceed $5 \%$.

At the midday the accuracy of measurements is lower than in the morning and evening.

For the second experimental group of 102 cows (also of different ages and stages of lactation), similar indicators ( $\mathrm{M} \pm \mathrm{m}$ and limits) per day are equal: milk yield $25.6 \pm 0.7 \mathrm{~kg}$, $(\lim 10.3-45.4 \mathrm{~kg})$; fat $\% 3.89 \pm 0.06 \%$, $(\lim 2.83-5.08 \%)$; protein $\% 3.22 \pm 0.01 \%$, $(\lim$ 2.98-3.35\%).

Table 4. Calculation of daily milk productivity in group №1 by coefficients for one milking, $n=83$.

\begin{tabular}{|l|c|c|c|c|c|c|c|c|c|c|}
\hline \multirow{3}{*}{ Indicator } & \multicolumn{8}{|c|}{ Yaily milk productivity } \\
\cline { 2 - 11 } & \multicolumn{7}{|c|}{ Yass fraction of fat, \% } & \multicolumn{2}{c|}{ Mass fraction of protein \% } \\
\cline { 2 - 11 } & morning & midday & evening & morning & midday & evening & morning & midday & evening \\
\hline $\mathrm{M}$ & 25.36 & 25.51 & 25.30 & 4.03 & 4.03 & 4.03 & 3.12 & 3.12 & 3.13 \\
\hline$\pm \mathrm{m}$ & 0.78 & 0.83 & 0.78 & 0.09 & 0.09 & 0.09 & 0.01 & 0.01 & 0.01 \\
\hline $\begin{array}{l}\text { Difference } \\
\text { between } \\
\text { calculated } \\
\text { with actual }\end{array}$ & 0.019 & 0.13 & 0.087 & 0.003 & 0.00 & 0.004 & 0.00 & 0.0003 & 0.010 \\
\hline td diffreneces & 0.018 & & & & & & & & \\
\hline & & & & & & & & \\
\hline $\mathrm{r}$ & 0.117 & 0.081 & 0.027 & 0.002 & 0.029 & 0.00 & 0.0198 & 0.10 \\
\hline tr & 37.9 & 31.1 & 36.8 & 30.9 & 8.67 & 30.9 & 29.4 & 5.79 & 29.4 \\
\hline
\end{tabular}

Note: td - the criterion of difference authenticity;

$\mathrm{r}$ - correlation coefficient;

tr - criterion for reliability of the correlation coefficient.

Similar indicators were obtained for group № 2 .

For the second experimental group, similar coefficients for indicators recalculation for milking into daily values were also found. Now it is enough to multiply the indicator for one milking by the corresponding coefficient to get productivity per day for cows of group №2.

To calculate the daily data, the recalculation coefficients obtained for 102 cows of the second experimental group were taken from their conversion coefficients (group № 2). The results obtained showed the same regularities for group №2 as were obtained for group № 1 .

Further, in the second experimental group, when calculating the daily productivity for one milking, the indicators recalculation coefficients for milking were taken into the daily groups №1 obtained six months earlier (table. 5).

Table 5. Calculation of daily milk productivity in cows group №2 $(\mathrm{n}=102)$ by coefficients for one milking of group №1 $(\mathrm{n}=83)$.

\begin{tabular}{l|c|c|c|c|c|} 
Indicators & $\mathbf{M}$ & $\mathbf{m} \pm$ & Difference & td & Paired
\end{tabular}




\begin{tabular}{|l|c|c|c|c|c|c|}
\hline & & & $\begin{array}{c}\text { between } \\
\text { calculated } \\
\text { and actual }\end{array}$ & differences & \multicolumn{2}{c|}{$\begin{array}{c}\text { correlation of } \\
\text { calculated and } \\
\text { actual indicator }\end{array}$} \\
\cline { 5 - 7 } & & & & & r & tr \\
\hline Cows daily productivity: & & & & & & \\
\hline Actual: & & & & & & \\
\hline Yield, kg & 25.61 & 0.72 & & & & \\
\hline Fat, \% & 3.89 & 0.06 & & & & \\
\hline Protein, \% & 3.22 & 0.01 & & & & \\
\hline Calculated productivity for & & & & & & \\
day by milking & & & & & & \\
\hline Yield, kg: & & & & & & \\
morning & 25.59 & 0.75 & 0.017 & 0.016 & 0.998 & 63.3 \\
midday & 25.75 & 0.76 & 0.146 & 0.140 & 0.903 & 21.0 \\
evening & 25.50 & 0.75 & 0.109 & 0.104 & 0.987 & 62.4 \\
\hline $\begin{array}{l}\text { Fat \% } \\
\text { morning }\end{array}$ & 3.90 & 0.06 & 0.006 & 0.065 & 0.978 & 46.7 \\
midday & 3.89 & 0.06 & 0.009 & 0.098 & 0.978 & 46.6 \\
evening & 3.90 & 0.06 & 0.006 & 0.073 & 0.845 & 15.8 \\
\hline $\begin{array}{l}\text { Protein \% } \\
\text { morning }\end{array}$ & & & & & & \\
midday & & & & & \\
evening & 3.22 & 0.01 & 0.001 & 0.041 & 0.973 & 41.9 \\
\hline
\end{tabular}

Note: the same as for table 4.

The same regularities were obtained with the same accuracy as in group №1. This proves the validity of the method for determining the daily productivity of cows for one milking within six months after determining the coefficients.

This method of calculating the milk productivity of cows group №1 was tested using recalculation coefficients obtained six months later for cows group № 2 (table. 6).

Table 6 shows that the calculation of the daily productivity of cows group №1 based on the recalculation coefficients taken from group № 2, obtained six months later, led to results that copy the actual milk yield, fat $\%$, and protein $\%$ with an accuracy exceeding $0.01 \%$ error (for $\mathrm{td}$ ). At the same time, the correlation of paired indicators (calculated and actual) is extremely high $(\mathrm{r}=0.737-0.986)$, as well as the reliability of the correlation $(\mathrm{tr}=$ 10.9-53.9).

These data make it clear that the calculation of daily productivity for daily yield one milking is justified based on indicators obtained six months earlier.

Thus, the data from tables 5 and 6 show that it is possible to determine cows daily milk productivity (milk yield, mass fractions of fat and protein) with high enough accuracy based on the recalculation coefficients obtained for six months, both before and after, that is, during the year, with the same type of year-round feeding, keeping and milking mode.

In our experience, $25 \%$ more time is spent on analysis during control milking with determination of milk yield and sampling.

In determining the daily productivity of cows for one control milking out of three, the productivity of the machine milking operators and the laboratory assistant increases by 3 times (table. 7).

Table 6. Calculation of daily milk productivity in cows of group №1 ( $\mathrm{n}=83$ ) by coefficients of group №2 for one milking.

\begin{tabular}{|c|c|c|c|c|c|}
\hline Indicators & $\mathbf{M}$ & $\mathbf{m} \pm$ & $\begin{array}{c}\text { Difference } \\
\text { between } \\
\text { calculated } \\
\text { and actual }\end{array}$ & $\begin{array}{c}\text { td } \\
\text { differences }\end{array}$ & $\begin{array}{c}\text { Paired } \\
\text { correlation of } \\
\text { calculated and } \\
\text { actual indicator }\end{array}$ \\
\hline
\end{tabular}




\begin{tabular}{|l|c|c|c|c|c|c|}
\hline & & & & & r & tr \\
\hline Cows productivity for day: & & & & & & \\
\hline Actual: & & & & & & \\
\hline Yield, kg & 25.38 & 0.75 & & & & \\
\hline Fat, \% & 4.03 & 0.09 & & & & \\
\hline Protein, \% & 3.12 & 0.01 & & & & \\
\hline Calculated productivity for & & & & & & \\
day in milking & & & & & & \\
\hline Yield, kg: & & & & & & \\
morning & 25.36 & 0.78 & 0.019 & 0.018 & 0.986 & 53.7 \\
midday & 25.28 & 0.82 & 0.102 & 0.092 & 0.851 & 14.6 \\
evening & 25.50 & 0.78 & 0.115 & 0.106 & 0.986 & 53.9 \\
\hline Fat \% & & & & & & \\
morning & 4.02 & 0.09 & 0.010 & 0.083 & 0.976 & 40.2 \\
midday & 4.03 & 0.09 & 0.000 & 0.002 & 0.892 & 13.0 \\
evening & 4.03 & 0.09 & 0.005 & 0.036 & 0.976 & 40.2 \\
\hline $\begin{array}{l}\text { Protein \% } \\
\text { morning }\end{array}$ & & & & & & \\
midday & 3.12 & 0.01 & 0.000 & 0.008 & 0.979 & 42.9 \\
evening & 3.12 & 0.01 & 0.003 & 0.198 & 0.773 & 10.9 \\
\end{tabular}

Note: the same as for table 4.

Table 7. The effectiveness of the proposed method for determining milk productivity under the cows three times milking method per day.

\begin{tabular}{|l|c|c|}
\hline \multirow{2}{*}{ Indicator } & \multicolumn{2}{c|}{ Methods } \\
\cline { 2 - 3 } & $\begin{array}{c}\text { 1 conventional } \\
\text { (prototype) }\end{array}$ & $\begin{array}{c}\mathbf{2} \\
\text { suggested }\end{array}$ \\
\hline Average daily milk yield per cow: & 21.0 & 21.0 \\
$\begin{array}{l}\text { Milk amount, kg } \\
\text { Mass fraction, \%: }\end{array}$ & 3.52 & 3.84 \\
fat & 3.19 & 3.20 \\
protein & & \\
\hline $\begin{array}{l}\text { Labor costs per day per person / min for control } \\
\text { milking per 1 cow: }\end{array}$ & 1.8 & $0.06^{* *}$ \\
The operator of machine milking & $(3 \times 1)=12.0$ & \\
Research assistant-accounting clerk & 0.5 & 0.5 \\
\hline $\begin{array}{l}\text { Labor costs in the laboratory for analyzing milk } \\
\text { from one cow, person / min }\end{array}$ & - & $0.5^{* *}$ \\
\hline $\begin{array}{l}\text { Labor costs for calculating milk productivity per } \\
\text { day for 1 cow, person / min }\end{array}$ & 14.3 & $4.6^{* *}$ \\
\hline Total labor costs per 1 cow, person / min & \\
\hline
\end{tabular}

Notes: 1 - conventional method. Control milking was carried out in all three milkings with the average milk sample per day for a cow.

2 - the suggested method, determining by 1 control milking.

** - difference with the prototype with $\mathrm{P}<0.05$.

When this work is carried out once a month, 2 milking sessions 0.25 of working day each or 0.5 working days of the operator and 0.5 working days of the laboratory assistant are saved, for a total of 1 working day.

The savings are: if the cost of work is 1000 rubles / shift, these are 1000 rubles with a load of 50 cows/person per shift, or $1000 / 50=20$ rubles / per cow per month or 240 rubles per year (12 months $\times 20$ rubles). This is the case when the control milking frequency is 1 per month. 
The method has a novelty and can be used in modern dairy farms, livestock complexes and farms.

Thus, based on the example of a specific application of the claimed method, a reduction in labor costs and working time of operators and laboratory assistants was achieved for determining the dairy productivity of cows per day, as well as reducing the stress load on animals.

\section{Conclusions}

The method for determining cows' milk productivity includes accounting the amount of milk and the concentration of fat and protein in it separately for each milking, finding the same indicators for a day, calculating the conversion coefficients of the amount of milk and the mass fraction of fat and protein for each milking into daily indicators, calculating the indicators for a day based on data for one milking and conversion coefficients according to the developed formulas.

2. To more accurately determine the milk productivity of cows per day, indicators are used for one single milk yield after a longer interval between milkings.

3. This method of determining the dairy productivity of cows per day is used on dairy cows from the tenth day of lactation and more.

4. This method of determining the milk productivity of cows allows you to increase the accuracy of research and three times reduce labor costs, reduce the stress load in cows.

\section{References}

1. V.T. Golovan, E.V. Golovan, M.S. Galicheva, V.I. Bondarenko, A device for milk sampling from the container: the patent for the invention, The patent for the invention № 2586896. Byul. № 16 (2016) https://www.fips.ru/iiss/document.xhtml?facesredirect $=$ true\&id=a6a59d8225c6ec015b2a5269808f2471

2. D.B. Jonson, M. van Voort, H. Hogeveen, J. Dairi Sci. 101, 10428-10439 (2018) https://doi.org/10.3168/jds.2017-14134

3. S.I. Fyl, E.I. Fedorovich, P.V. Bodnar, Animal Breeding and Genetics 57, 136-142 (2019) https://doi.org/10.31073/abg.57.16

4. N. Aslam, M. Abdullah, M. Fias, J. A. Bhatti, Z.M. Igbal, N. Bangulzai, C.W. Choi, Hwan Jo, Journal of Animal Science and Technology 56, 13 (2014) https://www.janimscitechnol.com/content/56/1/13

5. L.V. Karlova, O.V. Lesnovska, I.V. Deberina, O.G. Gavrilina, Ukrainion Journal of Ecology 9(2), 136-143 (2019) https://www.jecology.com/articies/

6. S.I. Fyl, E.I. Fedorovych, P.V. Bondar, Scientific Messenger of LNU of Veterinary Medicine and Biotechnologies. Series: Agricultural Sciences 21(90), 68-75 (2019) https://doi.org/10.32718/nvlvet-a9012

7. K.N. Dominiak, A.R. Kristensen, Comput. Electron. Agric. 133, 46-67 (2017) https://doi:10.1016/j.compag.2016.12.008

8. D.B. Jensen, M. van der Voort, H. Hogeveen, J. Dairy Sci. 101, 10428-10439 (2019) https://doi.org/10.3168/jds.2017-14134

9. F.X. Wang, D.F. Shao, S.L. Li, Y.J. Wang, A. Azarfar, Z.J. Cao, J.Dairy Sci. 99, 37093717 (2015) https://doi:10.3168/jds.2015-10098

10. D.W. Pitta, N. Indugu, L. Baker, B. Vecchiarelli, G. Attwood, J. Dairy Sci. 101, 76617679 (2018) https://doi.org/10.3168/jds.2017-13858 
11. M.T. Gorczyca, K.G. Gebremedhin, Department of Biological and Environmental Engineering (Cjrnell University, Ithaca, US, 2019) https://doi.org/10.1016/j.cjmpag.2019.105124

12. D.J. Rezac, K.N. Grigsby, N.M. Bello, B.J. Bradford, J. Dairy Sci. 95, 842-849 (2012) doi:10.3168/jds.2011-4752

13. K.D.Hart, B.W. McBride, T.F. Duffield, T.J. DeVries, J.Dairy Sci. 96, 6973-6985 (2013) http://dx.doi.org/10.3168/jds.2013-6764

14. J. Oh, M. Harper, F. Giallongo, D.V. Bravo, E.H. Wall, A.N. Hristov, J. Dairy Sci. 101, 1888-1901 (2017) https://doi.org/10.3168/jds.2016-11665

15. D.M. Bickhar P.J. Weimer, J. Dairy Sci. 101, 7680-7689 (2018) https://doi.org/10.3168/jds.2017-13328

16. B.A. Saylor, D.H. Min, B.J. Bradford, J. Dairy Sci. 101, 5984-5990 (2018) https://doi.org/10.3168/jds.2017-14118 